\title{
I played for my father
}

\author{
Margaret O'Sullivan \\ University of British Columbia, Canada
}

In this paper the author uses creative non-fiction to story a formative life event in a reflection on how music learning was critical to her survival, self-repair and self-making. The paper centres on relationship, adolescent trauma, and critical loss, and how physical and ethereal spaces of healing can be found in the music room and in music learning and making. The potential for literary forms of scholarly inquiry to connect the personal experiences of both writer and reader is explored, as deeply rooted memories invoke selfcompassion, and deepen empathy and awareness amongst music educators, teachers, and in the scholarship of music learning and making.

Keywords: storying memory, critical loss, adolescent trauma, self-making, becoming

Personal narratives propose to understand a self or some aspect of a life as it intersects with a cultural context, connect to other participants as coresearchers, and invite readers to enter the author's world and to use what they learn there to reflect on, understand, and cope with their own lives (Ellis 2004, 46).

\section{The Mock Inquiry}

Remnants of dinner on plates piled high beside soaking pots and pans. I'm leaning against the sink, my arms softly folded, the peachy light of an endless late September sunset warming my back. My father is ironing, gradually reducing a stack of wrinkled clothes to an orderly pile. I linger, wilfully ignoring the afterdinner chaos, savouring this quiet time when conversation might happen.

"Somebody, I'm not sure who, but somebody ... has been playing my records," my father grins as he presses the steaming iron to the collar of a shirt.

I smile shyly, enjoying the mock inquiry, my awkwardness tempered by suppressed delight at the attention.

"Really? Why would somebody be listening to your records? I mean, it's all boring opera and stuff?" I counter.

(C) Margaret O'Sullivan. The content of this article is the sole responsibility of the author. The ACT Journal and the Mayday Group are not liable for any legal actions that may arise involving the article's content, including, but not limited to, copyright infringement. 
He flashes me his trademark single eyebrow raise. Feigning concentration on the serious task of ironing, he speaks to me.

"Well, imagine this-the Mozart Piano Concerto, you know the one with the lovely slow bit that I played in the car, from Elvira Madigan?"

My father glances at my reddening face.

"It was in the wrong sleeve, mixed up with Tchaikovsky's $5^{\text {th }}$ symphony? Imagine that."

He is twinkling at me, tenderly relishing my embarrassment.

"Somebody must have broken into the house to listen to music. Isn't that gas? A cultured burglar."

I don't know why I'm embarrassed to admit it was me, but everything seems to embarrass me these days. I've been a passive listener to this music all my life. My father's vast record collection is deeply familiar to me, containing hundreds of recordings of music from Renaissance polyphony right up to the middle of the twentieth century, slowing down somewhere around Shostakovich, skidding to a halt at Bernstein. Our car journeys are often sites of musical negotiation-one full Symphony in exchange for a whole cassette of Bob Dylan, Rory Gallagher or whoever happens to be in the charts. Brahms' violin concerto or Joan Sutherland's luminous soprano will accompany dinner, no matter how humble the fare. Blasting Beethoven's 5th Symphony at top volume during early morning hoovering rounds is my father's occasional Sunday morning strategy for waking his slumbering teenage daughters.

I let down my thirteen-year-old guard and own up.

"You remember that day ye went to the wedding?"

A momentous day for my little sister and I, as we had been entrusted to spend a whole day at home without adult supervision.

"Yea, and ye surprised us by washing your mother's car."

Daddy rests the iron on its base and straightens up to look at me.

I shrug and respond to his teasing.

"Well, I might have been listening to a few records that day."

His golden smile warms me, like the sun at my back.

"Aha, I knew it. Well, which did you like? What did you listen to? Was it the Mozart or the Tchaikovsky, or both?”

A clattering sound interrupts our conversation. It's my mother in her gardening boots, filling a watering can outside the window. Waving in at us, she 
gestures in mock disapproval at the sink full of dishes. Her eyes meet my father's, and they smile.

\section{One week later, after the 'great divide'}

A long line of people, some familiar, many men in tears. The centre aisle of our local church is three deep. Those nearer the altar trudge with grim attention, silent as they move to the front of the line. The volume of chatter and greetings increasing back along the middle aisle is like a soundwave building to a crescendo through the door and out into the churchyard. Our parish is mobilised for a major event. ${ }^{2}$

My sisters, my mother, and I sit in a line across the front benches of the church. Our aunts and uncles, cousins, and friends flank us in protective rows. My grandmother clutches my mother's hand.

Endless people want to comfort us, to touch us, utter useless words, express their sorrow with our sorrow. The coffin holding my father's body rests on a trestle in front of the altar where it will remain overnight. We are numb, raging, quietly sobbing, dazed, stupefied, talking too brightly and for too long with each mourner, hearing and repeating the same phrases and inanities over and over. As the ritual three-day funeral goes on, each of us differently folds in on herself. We sit or stand side-by-side to greet people. We cry more than we ever have or ever will. We cannot know then that we will never really know togetherness again-a chasm has opened between us and our lives. 3

I watch my mother. I watch everybody. I listen to every syllable spoken in tribute to my father by the polyphony of voices from hundreds of mourners whose presence I both crave and despise.

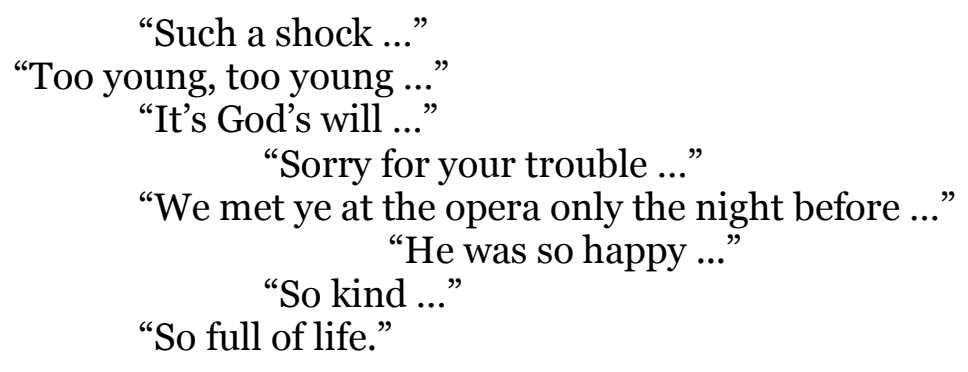

It is a cacophony of sound. While they swarm around us, he is still a reality. When all goes quiet, the thundering finality can no longer be denied.

I feel my hand being taken. 
“Your Daddy would have loved the music, wouldn't he? Wasn't the singing beautiful?”

An old neighbour from the street where we used to live, where my father had grown up, and his mother before him, speaks in a sincere tone. So many people are at a loss for words when they reach the end of the line where my ten-year old sister and I sit. I meet her eyes and nod, and she moves off as the next person comes along.

For years I recall every note and every word of the song my father's tenor friend sang for him that evening, as the rain hammered on the roof of the church. Writing this down for the first time, I realise that I no longer know what the song was or how it goes. But I can still feel and sense the comforting tender words, the ebb and flow of the phrasing, the sparse accompaniment on harmonium, the sob of the melody. I think about how my father would have listened and cocked an eyebrow in mortified appreciation.

\section{Playing my longing for everything to return to how it had been}

The parish priest pays a visit to our darkened house a month after the wake. It must be mid-term because I'm home from school. My mother is exhausted from wellmeaning visitors keeping nightly vigil. While she sits with the parish priest, graciously accepting his comforting platitudes about my father being in a 'better place,' I excuse myself and slip out to the dining room. It is too late to reveal to my father that I'm secretly playing the piano. There will be no more playful, stolen chats with him, or with anyone. The death of one parent makes a ghost of the other.

I start to pick out notes on the keyboard. Soon I am lost in the repeated motifs and arpeggio runs of Beethoven's Für Elise. I neither hear the door open, nor notice the figure standing in the gloom of the room until I finish.

"That was beautiful," Father Mac says softly.

"Oh, thanks," I mutter, startled by the intrusion into my private musical domain.

Though I appreciate his intentions I resent his presence. I don't remember him visiting in our 'before-life.' He is standing a few feet away as I remain seated on the piano stool. I don't know what to say.

"Maybe the next time I come you will play some happier music," he suggests, a little desperately. 
“Maybe," I say politely, unable to contradict a priest. I'm thankful when he lets himself out of the house.

I pause and think about what he said. Is Für Elise a sad piece? I don't think so. I think it's a romantic piece-it makes me feel part of something bigger, connected to a wider world, both of the past, and of the future. I like to play it briskly, not too fast but with forward momentum. No lingering, dribbling around the opening notes like some of my friends when they play it.

What did he hear when I played?4 Did he hear what he wanted to hear? Or was I hearing an alternative rendering in my mind, different from the sound I was producing? Was my playing suffused with the heavy sadness I woke up with every morning? Did the heaviness in my chest weigh down my phrasing? Was I playing my longing for everything to return to how it had been before?

\section{Stepping out of time}

Back in boarding school after the funeral I take refuge in the music room. My thirteen-year-old self instinctively embarks on a journey of music-and selfmaking. Largely independently, I speed through grade exams with minimal guidance from the nun who is my piano teacher. Teachers turn a blind eye when I disappear from study periods to practice for hours on end. As tears and words fail me, I play and I play. Recognized by my school as the main organist and pianist, I relish my position at the back of the church-mastering the possibilities of the pipe organ with both feet and hands, choosing repertoire for countless masses and services, accompanying choirs, and devouring full piano scores for West Side Story, Cats, and The King and I for the annual school musical. I drive myself hard to achieve total immersion in music as a way of re-making myself in the aftermath of defining loss and trauma, and as a way of crafting 'good' out of the sorrow, for my family and for myself. In the intervening years, the piano becomes less and less of a presence, but I keep music at the core of my work and life choices. Perhaps because of my particular experience I am drawn to a career in arts education, creating opportunities for children and young people, particularly those who are excluded, to experience the sustaining and reparative presence in their lives of access to art and music, as I am privileged to have had in my life at a time of rupture and defining loss. 


\section{Keep moving forward}

I am now the age that my father was when he died. I have choices and opportunities that he could not have dreamed possible. I work and study fulltime in the field of music education. I'm rusty on the piano, but I can still play most of Für Elise from memory. I discover a piano in the library commons and play it after writing this story. I'm excited to bring it to life. It's a digital piano. The keys feel clunky, my nails are too long, and I'm wearing tight-fitting headphones. I start to pick out notes on the keyboard. I do not linger on the opening notes, but I falter and have to re-start a couple of times. A gear shifts in my brain. Soon, I am lost in the repeated motifs and I want to keep moving forward.

For the first time, I played for my father.

\section{Endnote}

We are shaped by our memories and circumstances, and each and every morning we awake to carry ourselves and who we are into the world and see what happens. (Goodall 2006, 348)

Rather than construct a "factual," point-by-point account of a formative life event, this creative non-fictional story 5 represents personal memories from my experience of my father's life and death. This mode of writing enabled me "to use alternative and engaging approaches to create an art of scholarly inquiry" (Gouzouasis et al 2013, 14). His presence in my life was, for many years, eclipsed by the devastating effects of his sudden death. Recalling three fragmented scenes from before and after this formative life event, I represent deeply rooted memories of my thirteen-year-old self-connecting with my father, and of my becoming 6 (Rogers 1961; Biesta 2013) self through engagement with music, to evoke the presence of music as a core element of my survival, self-repair and self-making. Memories expressed as narratives are changed with each telling and re-telling, as understanding is gained through ongoing and continuing "experience of the experience" (Ellis and Bochner 1992, 98; Ellis 1993, 711). Fearful that writing these memories into the "record" will fix them as an official account and damage their ethereal nature, I have reconstructed three inter-connected scenes that allow me to re-story my relationship with my father through musical connections that took on deeper meaning because of his sudden death, and continue to resonate and shape my life long after the events described. 


\section{Acknowledgements}

I wrote the first draft of this piece in an autoethnography methods class with my doctoral supervisor Prof. Peter Gouzouasis, to whom I am very grateful for both the encouragement and the provocation to commit to this way of writing. Gratitude also to Dr. Scott Goble for leading me to UBC. I am deeply indebted to my mother for her unwavering love and support for my choices in life, to my father who is so much a part of who I am, and to all my family, friends, and the musicians of all ages that I work with.

\section{About the Author}

Margaret O'Sullivan is a doctoral candidate in the Department of Curriculum and Pedagogy at the University of British Columbia, conducting arts-based research into understandings of quality in music education through the experiences of children and young people in community music education in Ireland. As founderdirector of the Music Generation Cork City program of performance music education, she has worked with community music groups to develop new approaches to partnership as a way of delivering music education opportunities in the community for children and young people at risk of exclusion. She has received funding awards for her studies from the National University of Ireland, and the Faculty of Education, UBC.

\section{References}

Baddeley, Jenna, and Jefferson A. Singer. 2010. A loss in the family: Silence, memory, and narrative identity after bereavement. Memory 18 (2): 198-207. doi: 10.1080/09658210903143858

Biesta, Gert. 2013. The beautiful risk of education. London, UK: Routledge.

DeNora, Tia 2012. Resounding the great divide. Theorising music in everyday life at the end of life. Mortality 17 (2): 92-105.

Ellis, Carolyn, and Arthur P. Bochner. 1992. Telling and performing personal stories: The constraints of choice in abortion. In Investigating subjectivity, edited by C. Ellis, and M. Flaherty, 79-101. Newbury Park, CA: Sage.

Ellis, Carolyn. 1993. "There are survivors": Telling a story of sudden death. The Sociological Quarterly 34 (4): 711-30.

Ellis, Carolyn. 2004. The ethnographic I: A methodological novel about autoethnography. Walnut Creek, CA: Altamira Press.

Goodall, Harold B. 2006. A need to know: The clandestine history of a CIA family. Walnut Creek, CA: Left Coast Press. 
Gouzouasis, Peter, Daniel Bakan, Jee Yeon Ryu, Helen Ballam, David Murphy, Diane Ihnatovych, Zoltan Virag, and Matthew Yanko. 2013. Where do teachers and learners stand in music education research? A multi-voiced call for a new ethos of music education research. International journal of education \& the arts 15 (15). http://www.ijea.org/v15n15/index.html

Joyce, James. 1922. Ulysses. Edited with an introduction and notes by Jeri Johnson. Oxford, UK/New York, NY: Oxford University Press.

Lee, Karen V. 2004. Riffs of change: Musicians becoming music educators. Unpublished doctoral dissertation. Vancouver, BC: University of British Columbia.

Lynch, Thomas 1997. The undertaking: Tales from the dismal trade. New York, NY: W.W. Norton.

Pelias, Ronald J. 2000. The critical life. Communication Education 49 (3): 22028.

Richardson, Laurel. 2000. Writing: a method of inquiry. In The handbook of qualitative research (2nd ed.), edited by N. K. Denzin and Y. S. Lincoln, 923-49. Thousand Oaks, CA: Sage.

Rogers, Carl. 1961. On becoming a person: A therapist's view of psychotherapy. Boston, MA: Houghton Mifflin.

Singer, Jefferson A., Pavel Blagov, Meredith Berry, and Kathryn M. Oost. 2012. Self-defining memories, scripts, and the life story: narrative identity in personality and psychotherapy. Journal of personality 81 (6): 569-82.

Sparkes, Andrew. 2007. Embodiment, academics, and the audit culture: A story seeking consideration. Qualitative Research 7 (4): 521-50.

Toolis, Kevin. 2017. My father's wake: How the Irish teach us to live, love, and die. London, UK: Weidenfeld and Nicolson.

Wong, Maria. 2009. I reach for rum. Qualitative Inquiry 15 (3): 499-502.

\section{Notes}

${ }^{1}$ DeNora (2012) explores music of the 'great divide', the everyday event of the end of life.

${ }^{2}$ Irish Catholic funerals are significant community events, particularly in rural and small-town localities. Children grow into a familiarity with the three-day ritual of the laying out and viewing of the body, visitations to the house of mourning, the 
removal to the church and the burial, interspersed with hospitality and a rare acceptance of public displays of emotion. Although some details have changed since the introduction of funeral homes and the crematorium, the ritual has remained essentially the same for centuries, as an inter-generational collective expression of solidarity. See My father's wake by Kevin Toolis (2017) for a journalist's autoethnographic account of deaths he has witnessed and the function of Irish funeral rituals; Thomas Lynch (1997) The undertaking: Tales from a dismal trade on the peculiar gift of his Irish heritage for life as an undertaker and a poet in Michigan, USA; and James Joyce' Ulysses (1922) in which Stephen Dedalus reflects on the death of his father, an ordinary Irish man, revealing the cultural significance of funerals in Irish life.

3 In families that experience critical loss, the surviving members often confront core questions of individual and collective identity. Stories that are shared, or not shared, to repair and stabilize fragile identities often evolve into self-defining memories (Baddeley and Singer 2010; Singer, Blagov, Berry and Oost, 2012).

4 DeNora (2012) observes how music offers threads with which to reconnect life and death [...] [and] is semiotically flexible-it affords many, and often contradictory, uses and interpretations (102).

5 I have been inspired by the form of creative non-fiction stories by Lee (2004), Wong (2009), Pelias (2000), Sparkes (2007), and Richardson (2000), to produce text that stories my experience using distinctly literary devices and techniques, including the present tense, chronological ordering of vignettes, and variation in voice to evoke a sense of being present (opening vignette) and a disassociating observational stance (the funeral).

${ }^{6}$ I use the notion of 'becoming' here, acknowledging the development of the concept by Rogers (1961) based on the psychological conceptualisation. I also use it to evoke a 'becoming' that may not be 'observable' using physiological or psychological means of determination, an inner private 'becoming' akin to potentiality (Biesta 2013) as an interior dimension of the unfolding subjectivity, self-making, and growth that a human being may experience in learning. 